\title{
Inhibitory Effect of Sodium Benzoate as Preservative Material in the Biogas Production in a Batch Anaerobic Digestion Process
}

\author{
Indro Sumantri ${ }^{*}$, Luqman Buchori', Didi Dwi Anggoro' \\ 1 Department of Chemical Engineering, Faculty of Engineering, Universitas Diponegoro, Semarang, Indonesia \\ * Corresponding author's e-mail: indrotekim@yahoo.com
}

\begin{abstract}
Sodium benzoate has been used a food preservative worldwide. The effect of sodium benzoate as a preservative in the wastewater treatment was examined from the biogas formation viewpoint. The research was conducted in batch mode reactor systems employing various ratios of activated sludge and solution of sodium benzoate volume. The MLSS of activated sludge used was $12 \mathrm{~g} / \mathrm{L}$, while the volume ratios of activated sludge and sodium benzoate ranged from 0 to $100 \%$. The concentrations of sodium benzoate used were 50,100 , and $200 \mathrm{mg} / \mathrm{L}$. The biogas samples were measured every two days for 60 days. The results showed that the volume ratio of activated sludge and sodium benzoate of $60 \%$ and $40 \%$ was a turning point where the existence of sodium benzoate influenced the formation of biogas. There were significant reductions of biogas formation from $200.6 \mathrm{~mL}$ to $66.6 \mathrm{~mL}, 159.8 \mathrm{~mL}$ to $66.0 \mathrm{~mL}$ and $130.2 \mathrm{~mL}$ to $54.0 \mathrm{~mL}$ for the initial $\mathrm{SB}$ concentrations of 50,100 , and $200 \mathrm{mg} / \mathrm{L}$. The kinetic parameters of the Modified Gompertz equation exhibited the greatest degree of confidence equal to $95 \%$.
\end{abstract}

Keywords: sodium benzoate, anaerobic, biogas, batch, Gompertz equation.

\section{INTRODUCTION}

Fresh product consumption has been increased in order to meet the consumer's demand of the healthy food. Unfortunately, the freshness and safety of fresh food product is strongly influenced by their microbial sensitivity to pathogenic bacteria (Chen et al., 2019). The effort to prevent food from deterioration can be conducted through several technologies, one of the ways is by the addition of food preservatives. The objective of the introduction of preservative substances is not only to eliminate the microbial activities to damage the food nutrients, but also to extend the life period of the food (Arias et al., 2019). Basically, the preservative agents inhibit the yeast and mold growth. The most commonly applied preservative agents in the food products are benzoic and sorbic acids and their salts of sodium, potassium and calcium (Piper and Piper, 2017). These preservatives are effective against the growth of a wide range of bacteria (Tfouni and Toledo, 2002a). Beside these substances, another group applied as a preservative agent of food product and also pharmaceuticals are parabens. Parabens are substances of $p$-hydroxybenzoic acid, with alkyl substituents ranging from methyl to pentyl or benzyl groups. The application of parabens as a preservative is popular because they are effective in inhibiting the activity of a wide broad spectrum of yeasts, molds and bacteria, chemical stability, having low production cost and no perceptible odor or taste (Błędzka et al., 2014). However, a disadvantage of using these chemical substances as preservative has been reported, at low doses. Benzoates trigger allergic reaction in some groups of humans (Jacob et al., 2016). Due to these disadvantages, the amount of benzoates and sorbates addition salts as simple preservatives which consumed by world population must be considered to prevent the adverse effects (Piper and Piper, 2017).

Sodium benzoate (SB) is widely used in food products, especially as complement food/seasoning such as: chili sauce, ketchup, tomato sauce, carbonated drinks, etc. (Sumantri et al., 2015) 
and is classified as generally recognized as safe (GRAS) by FDA (Shahmohammadi et al., 2016). The allowable limit of the SB application as preservative in the food products may differ from one country another. The Indonesian government declares the allowable limit is $1000 \mathrm{ppm}$ and is the same amount to FDA (Noorafshan et al., 2014). Dixit et al. (2008) reported that a concentration of $\mathrm{SB}$ as high as $2119 \mathrm{mg} / \mathrm{kg}$, exposed serious health risks to human. Previous studies to investigate the effects of SB using cells and animal models resulted in the linkage to the prevalence of urticana (Rajan et al., 2014), angiosderma (Nettis et al., 2004), asthma (Freedman, 1977), childhood hyperactivity (Egger et al., 1985), and other behavioral disorders [Beezhold et al., 2014; Noorafshan et al., 2014], cytostaticity [Mpountoukas et al., 2008], and genotoxicity [Pongsavee, 2015].

The aim of the research was to investigate the effect of various concentration ratios of SB and MLSS to the biogas production. Hitherto, the kinetic modeling of the biogas production from the degradation of SB in the activated sludge has not been reported yet. The kinetic model for rate of biogas production was conducted by means of a modified Gompertz equation. In this work, the production of biogas in batch anaerobic process was designed by various volume ratios of SB and MLSS concentration during 60 days digestion time in a series of $2 \mathrm{~L}$ polyethylene bottles and operated at room temperature (Budiyono et al., 2013). The data obtained from the experiments were applied to create the kinetic model of biogas production of SB degradation. Previous researchers conducted similar experiments in batch anaerobic process and operated at room temperature with glass bottles volume of $400 \mathrm{~mL}, 500 \mathrm{~mL}$ and 2,5 L (Yusuf and Ify, 2011).

\section{MATERIAL AND METHODS}

\section{Materials}

Sodium Benzoate ( $>98 \%$ purity) product of Sigma-Aldrich Corp was used as a preservative, sodium hydroxide and hydrochloric acid for controlling the $\mathrm{pH}$ were obtained from a chemical store. Sucrose was obtained from food store and activated sludge was the centralized wastewater treatment of tofu small-scale industry of Lamper Tengah, Semarang, Central Java, Indonesia.

\section{Acclimatization of activated sludge}

The anaerobic sludge utilized in this research was obtained from the Centralized Wastewater Treatment Plant of small-scale tofu industries at Lamper Tengah, Semarang Municipality. Sludge was taken by water sampler in the middle of anaerobic baffled reactor. Then, the sludge was concentrated by separating the water content until achieved the solid concentration of $12 \mathrm{~g} / \mathrm{L}$. The $\mathrm{pH}$ of sludge was set up at 7.0-7.5 by the addition of aqueous solution of sodium hydroxide or hydrochloric acid. The sludge was acclimated by $5 \mathrm{~g} / \mathrm{L}$ addition of sucrose performed every day for 60 days.

\section{Experimental set up}

A series of $2 \mathrm{~L}$ volume polyethylene bottles were used as anaerobic digesters. These bottles were plugged with a rubber plug and hermetically equipped with a valve to measure the biogas production. The system of the anaerobic digesters was designed for a batch system and operated at room temperature. The production of biogas during the digestion was measured using the water displacement method which also has been used by previous researchers (Syaichurrozi et al., 2013). In order to measure the biogas production, each of the digesters was connected to a gas collector to reserve gradual cylindrical glass. The connection of the digester and cylindrical glass was facilitated by a connecting plastic tube. The gas collector was immersed in water in order to complete sealing. The biogas produced from the digestion process was collected by reading of the downward displacement of water.

\section{Experimental design}

The batch system comprising $2 \mathrm{~L}$ volume polyethylene bottles was employed for the anaerobic digestion. The composition of the substrate in the system was composed with various mixture of the activated sludge and aqueous SB solution. The composition of the mixture was based on the proportional volume of the activated sludge and SB solution of $0 \%, 20 \%, 40 \%, 60 \%, 80 \%$ and $100 \%$ of the activated sludge. The $\mathrm{pH}$ condition of 7.0 for the mixture was set up by addition of $2 \mathrm{~N} \mathrm{NaOH}$ solution. A technical grade of $\mathrm{NaOH}$ crystal was used to prepare the $\mathrm{NaOH}$ solution. The design of experiments can be seen in Table 1 . 
Table 1. Variation of activated sludge and SB solution (MLSS activated sludge: $12,000 \mathrm{mg} / \mathrm{L}$ )

\begin{tabular}{|c|c|c|}
\hline \multicolumn{2}{|c|}{$\%$ Activated sludge : SB solution } & $\begin{array}{c}\text { Concentration of SB solution } \\
\mathrm{mg} / \mathrm{L}\end{array}$ \\
\hline Activated sludge & SB solution & \\
\hline $0 \%$ & $100 \%$ & \\
\hline $20 \%$ & $80 \%$ & \multirow{2}{*}{$50,100,200$} \\
\hline $40 \%$ & $60 \%$ & \\
\hline $60 \%$ & $40 \%$ & \\
\hline $80 \%$ & $20 \%$ & \\
\hline $100 \%$ & $0 \%$ & \\
\hline
\end{tabular}

\section{Experimental procedures}

The design of degradation during the digestion process was conducted for the retention time of 60 days. This degradation time was suggested from the literature of biogas production (Patil et al., 2012). The biogas production was measured every two days to quantify the biogas production using water displacement method. Each digester was mixed manually for one minute once a day.

\section{Kinetic model of biogas production}

The kinetics of biogas production applied in this research was a modified Gompertz equation (Syaichurrozi et al., 2013), which assumed that there is correlation of the biogas production kinetics in batch system of the specific growth of methanogenic bacteria in the batch system (Yusuf et al., 2011). The modified Gompertz equation can be expressed using the following equation:

$$
y(t)=A \cdot \exp \left\{-\exp \left[\frac{\mu e}{A}(\lambda-t)+1\right]\right\}
$$

where: $y(t)$ is cumulative of specific biogas production $(\mathrm{mL})$,

$A$ is biogas production potential (mL), $\mu$ is maximum biogas production rate $(\mathrm{mL})$,

$\lambda$ is lag phase period or minimum time to produce biogas (days), $\mathrm{t}$ is cumulative time for biogas production (days) and e is a mathematical constant (2.718282). The kinetics constants of $\mathrm{A}, \mu$, and $\lambda$ were determined through a non-linear regression (Budiyono et al., 2010).

\section{RESULTS AND DISCUSSIONS}

\section{Biogas production}

The condition of parameter of experiments in Table 1 was converted into Table 2 in order to indicate the concentration of activated sludge and organic load of SB, and also the total volume of biogas production. The sludge concentration can be calculated from the percentage of activated sludge

Table 2. Calculation of sludge concentration, organic load of SB, and cumulative biogas production for digestion time of 60 days

\begin{tabular}{|c|c|c|c|c|c|c|c|c|c|c|}
\hline \multicolumn{2}{|c|}{ Activated sludge } & \multicolumn{2}{|c|}{ SB solution } & \multirow{4}{*}{$\begin{array}{c}\text { Sludge } \\
\text { concentration } \\
\text { (MLSS) (mg/L) }\end{array}$} & \multicolumn{6}{|c|}{ Initial concentration of SB (mg/L) } \\
\hline \multirow{3}{*}{$\begin{array}{c}\% \\
\text { volume }\end{array}$} & \multirow{3}{*}{$\begin{array}{l}\text { Volume } \\
(\mathrm{mL})\end{array}$} & \multirow{3}{*}{$\begin{array}{c}\% \\
\text { volume }\end{array}$} & \multirow{3}{*}{$\begin{array}{l}\text { Volume } \\
\text { (mL) }\end{array}$} & & \multicolumn{2}{|c|}{50} & \multicolumn{2}{|c|}{100} & \multicolumn{2}{|c|}{200} \\
\hline & & & & & \multicolumn{6}{|c|}{ Organic load of SB (mg/L) and biogas volume $(\mathrm{mL})$} \\
\hline & & & & & $\mathrm{OL}(\mathrm{mg} / \mathrm{L})$ & Biogas $(\mathrm{mL})$ & $\begin{array}{c}\mathrm{OL} \\
(\mathrm{mg} / \mathrm{L})\end{array}$ & $\begin{array}{c}\text { Biogas } \\
(\mathrm{mL})\end{array}$ & $\mathrm{OL}(\mathrm{mg} / \mathrm{L})$ & $\begin{array}{c}\text { Biogas } \\
(\mathrm{mL})\end{array}$ \\
\hline 0 & 0 & 100 & 2000 & 0 & 50 & 0 & 100 & 0 & 200 & 0 \\
\hline 20 & 400 & 80 & 1600 & 2400 & 40 & 48,6 & 80 & 37.4 & 160 & 38.6 \\
\hline 40 & 800 & 60 & 1200 & 4800 & 30 & 66,6 & 60 & 66.0 & 120 & 54.0 \\
\hline 60 & 1200 & 40 & 800 & 7200 & 20 & 200,6 & 40 & 159.8 & 80 & 130.2 \\
\hline 80 & 1600 & 20 & 400 & 9600 & 10 & 355.4 & 20 & 342.2 & 40 & 321.0 \\
\hline 100 & 2000 & 0 & 0 & 12000 & 0 & 394.2 & 0 & 394.2 & 0 & 394.2 \\
\hline
\end{tabular}

Organic load: $\mathrm{V}_{\mathrm{SB}} \times \mathrm{C} / \mathrm{V}_{\mathrm{T}}$ where: $\mathrm{V}_{\mathrm{SB}}$ : volume of sodium benzoate added $(\mathrm{mL})$; $\mathrm{C}$ : concentration of sodium benzoate $(\mathrm{mg} / \mathrm{L})$ and $\mathrm{V}_{\mathrm{T}}$ : total volume $(2000 \mathrm{~mL})$. 


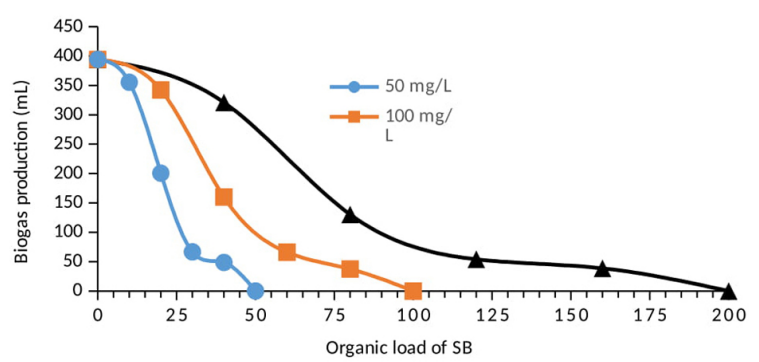

Figure 1. Total biogas production for various organic load and concentrations of SB for time of digestion of 60 days.

in every stage of variable and organic load was calculated of $\mathrm{QC} / \mathrm{V}$ where $\mathrm{Q}$ is volume of $\mathrm{SB}$ solution, $\mathrm{C}$ is the $\mathrm{SB}$ concentration in solution, and $\mathrm{V}$ is total volume. Total accumulation of the biogas production, was based on the experimental variables. The daily and cumulative of biogas production for all variables can be indicated in Figure 2.

The total cumulative biogas production for each variable of experiment can be seen in
Figure 1 for the initial SB solution of 0,100 , and $200 \mathrm{mg} / \mathrm{L}$, respectively. The production of the biogas indicated that degradation of the organic substances occurred through four step processes (hydrolysis, acidogenesis, acetogenesis and methanogenesis). Increasing the organic load decreased the biogas production, with the increase of organic load the gradient of the line would be flatter. It showed that the slope of initial

a)

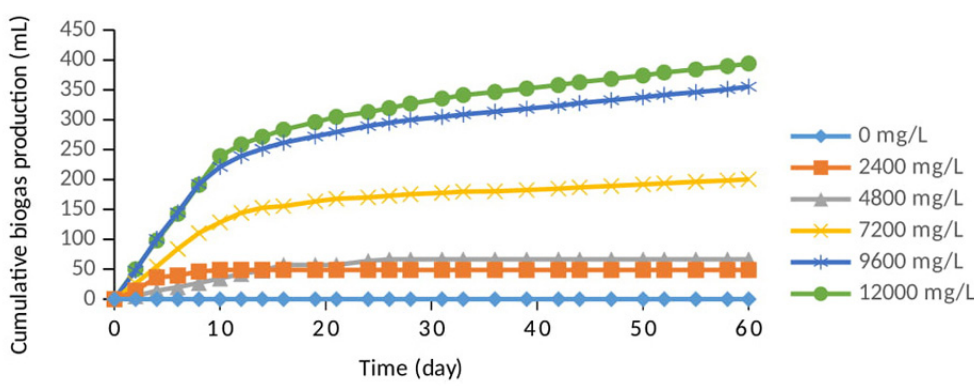

b)

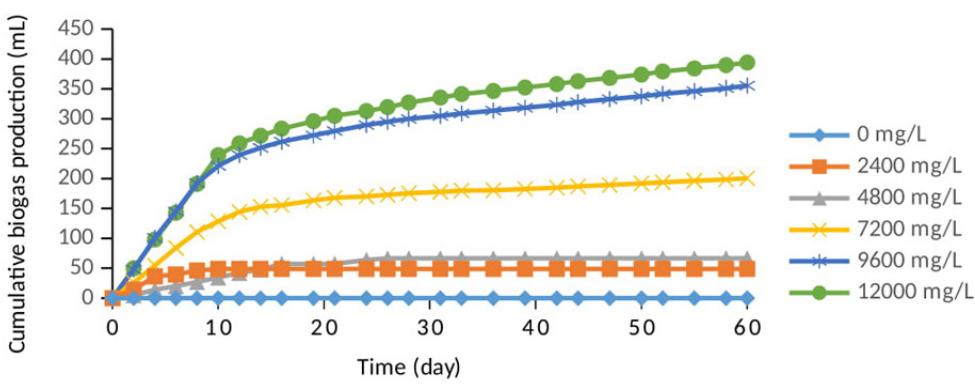

c)

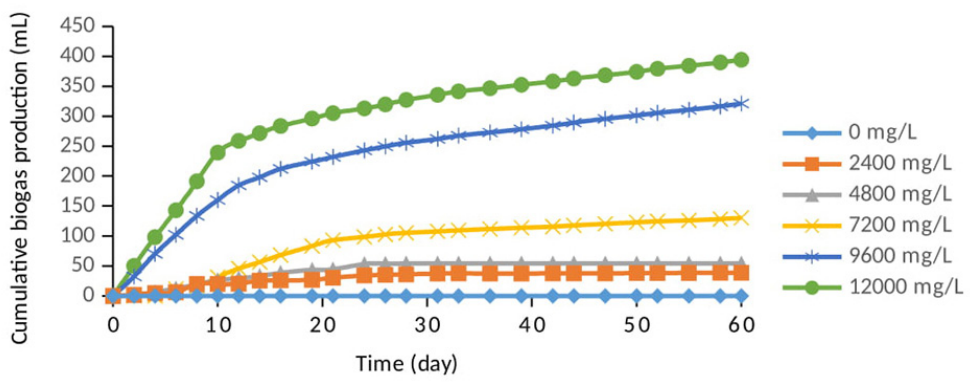

Figure 2. (a) Cumulative of biogas production with the initial SB concentration of $50 \mathrm{mg} / \mathrm{L}$ and MLSS concentration ( 0 - 12,000 mg/L); (b) of $100 \mathrm{mg} / \mathrm{L}$ and MLSS concentration (0 - 12,000 mg/L); (c) of $200 \mathrm{mg} / \mathrm{L}$ and MLSS concentration $(0-12,000 \mathrm{mg} / \mathrm{L})$ 
a)

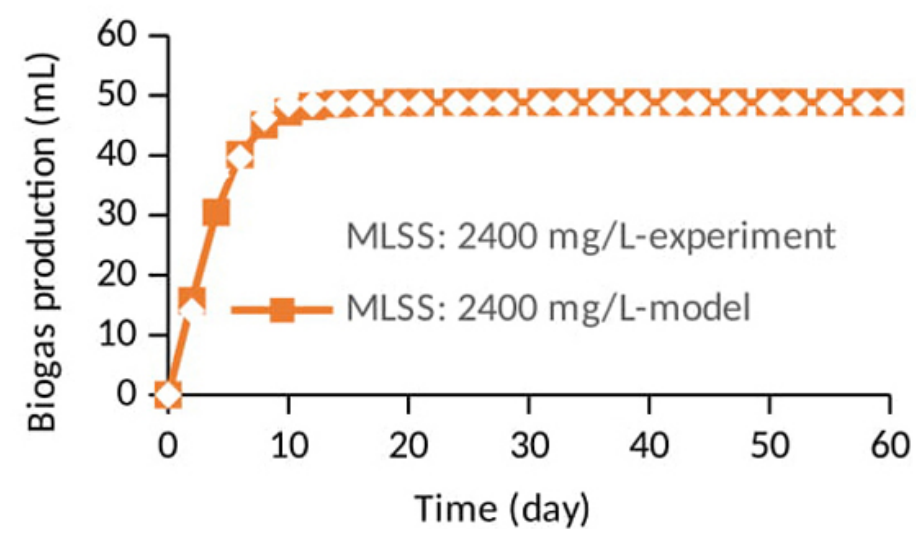

b)

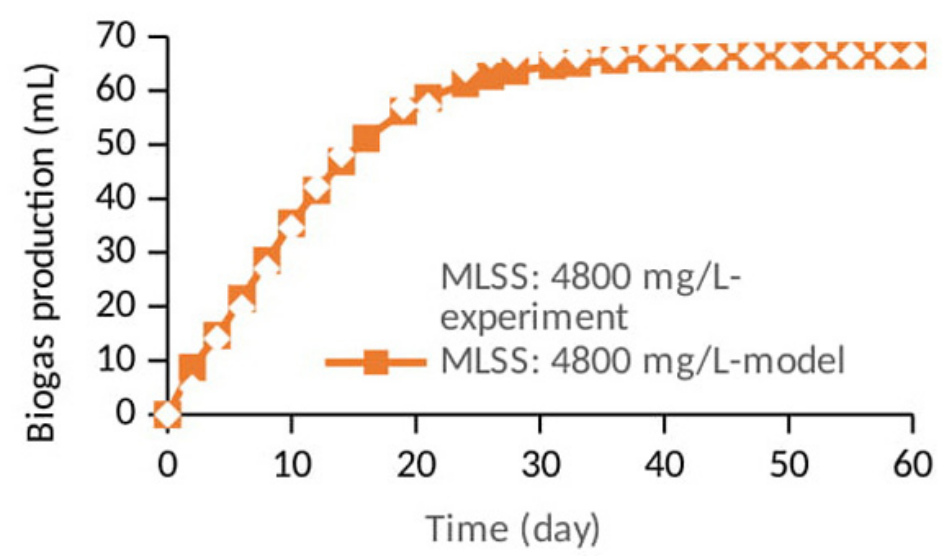

c)
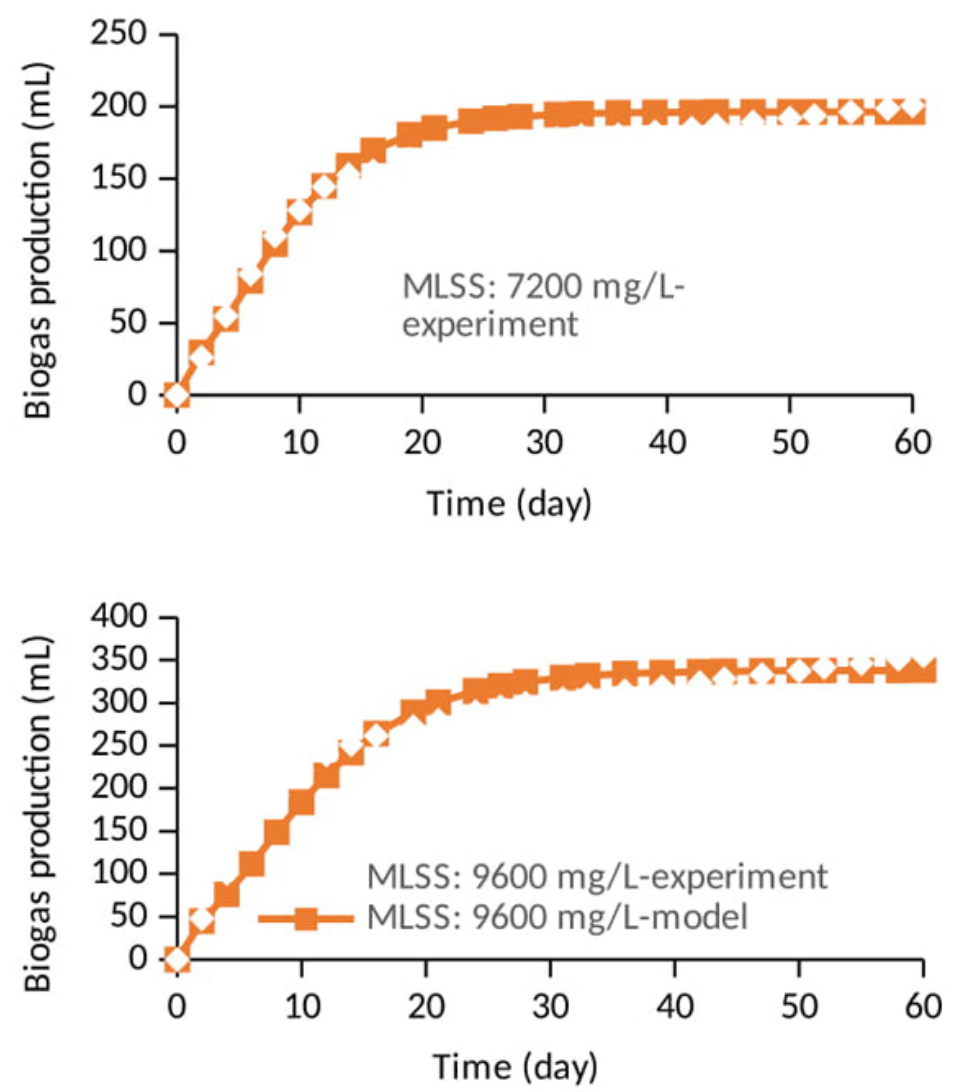

Figure 3. (a) Comparison of experimental data and a modified Gompertz model for the initial SB concentration of $50 \mathrm{mg} / \mathrm{L}$ with MLSS of 2,400 mg/L; (b) with MLSS of 4,800 mg/L; (c) with MLSS of 7,200 mg/L; (d) with MLSS of $9,600 \mathrm{mg} / \mathrm{L}$ 
concentration of SB of $50 \mathrm{mg} / \mathrm{L}$ was steeper than $100 \mathrm{mg} / \mathrm{L}$ and $200 \mathrm{mg} / \mathrm{L}$, and also the slope of the $100 \mathrm{mg} / \mathrm{L}$ was greater than $200 \mathrm{mg} / \mathrm{L}$.

Increasing the organic load of SB showed an increase of the SB concentration and less activated sludge. At the organic load of SB equal to zero, which indicated that there was no SB in the system and only activated sludge resulted the biogas production of $394.2 \mathrm{~mL}$. Meanwhile, for the system with no activated sludge, was no biogas production was obtained and it can be seen from the organic load of SB of 50, 100, and $200 \mathrm{mg} / \mathrm{L}$ respectively. The production of biogas during the digestion process resulted from an ability of the microbes in the activated sludge to degrade SB. When there was no activated sludge, only a solution of SB in the system, no biogas formation occurred due to the properties of SB as preservative agent reducing or eliminating the microbial activity (Chen et al., 2019). Hence, the biogas production was zero. Otherwise, for zero SB and only activated sludge in the system, biogas was produced in maximum, which was due to the activated sludge did not interfere in the degradation of the remaining organic compound in the solution.

In the anaerobic batch process condition, the quantity of activated sludge in the system plays an important role in the degradation of SB. Under the anaerobic condition, the SB degradation takes place under the reductive condition to form completed degradation to the path of ring fission and acetogenesis, and methanogenesis (benzoate $\rightarrow 3$ acetate $+\mathrm{CO}_{2}+3 \mathrm{H}_{2} \rightarrow \mathrm{CH}_{4}+\mathrm{CO}_{2}$ ) (Annachhatre and Gheewala, 1996; Jiang et al., 2016; Su et al., 2019). The control condition was ( $0 \%$ and $100 \%$ activated sludge) applied to observe the formation of biogas to the organic loading of SB to the system. Without activated sludge ( $100 \%$ of SB solution), no biogas production was obtained during 60 days observation. It indicated that SB effectively eliminates the microorganism growth and performed really well in preservation (Birck et al., 2016) due to the bacteriostatic and fungistatic properties (Yadav et al., 2016). It was indicated that without the existence of activated sludge, there is no biogas produced and the situation was opposite with the $100 \%$ activated sludge, which produced the highest biogas out of all other compositions (Esimbekova et al., 2017). At the concentration of sludge of $12,000 \mathrm{mg} / \mathrm{L}(0 \%$ of SB solution), the total accumulative biogas produced was $394.2 \mathrm{~mL}$. System of 100\% sludge resulted the highest biogas production due to the internal metabolism and long period degradation to the system with content of mixed liquor volatile suspended solid (MLVSS) and also remaining glucose from sucrose at the acclimatization in the solution would convert into the final product of biogas (Fujihira et al., 2018).

Figure 2 indicated that the biogas production was a function of the concentration of SB. Increasing the SB concentration would suppress the biogas production, as seen in Figure 2 ( $a, b$, and c), respectively. In the case of $100 \%$ of activated sludge it was indicated that the volume of the biogas was the highest than other composition. Activated sludge was also degraded during the anaerobic condition due to the decay of activated sludge in the endogenous respiration. Three types of digestion sludge occurred in the anaerobic process (liquefaction of solids, digestion of the soluble solids, and gas production) (Reynolds and Richards, 1995; Kondusamy and Kalamdhad, 2014). Without the SB solution, the highest volume could be achieved because the activity of SB involves eliminating the microorganism in the sludge, decreasing the sludge and also reducing the biogas production. For the first ten days, the cumulative of biogas production the product of biogas was high, while over 60 days it declined; however, no flat line was achieved. This showed that the degradation process had not finished yet for the sludge.

At the MLSS of $9600 \mathrm{mg} / \mathrm{L}(80 \%$ volume of MLSS), three types of SB concentrations (50, 100 , and $200 \mathrm{mg} / \mathrm{L}$ ) indicated the influence of the SB concentration on the gas production. Increasing the SB concentration also reduced the biogas production $(355.4,342.2$ and $321.0 \mathrm{~mL}$ ) and the reduction of the biogas production was approximately $8.3-23.9 \%$. High concentration of SB would result in a high reduction of biogas production. It meant that the microorganism in the activated sludge were able to degrade of SB as substance that inhibits the growth of wide range of bacteria (Zhang and Ma, 2013).

Meanwhile, at the MLSS of the $7200 \mathrm{mg} / \mathrm{L}$ or $60 \%$ volume of MLSS demonstrated a significant impact to the biogas production rate. The volume of biogas dropped from 355.4, 342.2 and $321.0 \mathrm{~mL}$ into 200.6, 159.8, and $130.2 \mathrm{~mL}$. In this composition, the interference of SB had to be considered due to the reduction of biogas of about $43.6 \%-59.4 \%$. The effect of biogas production rate reduction is proportional to the $\mathrm{SB}$ concentration. It showed that the properties of SB 
as disinfectant had successfully suppressed the microbe growth (Chen et al., 2019; Birck et al., 2016; Yadav et al., 2016).

For the MLSS less than $7200 \mathrm{mg} / \mathrm{L}$ or $60 \%$ volume MLSS (Figure 2) suggested not to be applied because the rate of biogas production was small. The balance of SB and microbe in activated sludge was dominated by the SB solution. Increasing the SB solution will prevent the activity of microbe involving degradation of the SB substance; hence, the formation of the biogas will also be reduced (Esimbekova et al., 2017).

\section{Kinetic model of biogas production}

The modified Gompertz equation was then used to predict the biogas production obtained from the experimental data (Budiyono et al., 2010). The equation is nonlinear, the kinetic constants of Gompertz equation (A, $\lambda$, and $\mu$ ) were determined by using non-linear regression and the value of those constants were presented in Table 3.

The employed model of principal kinetic patterns of biogas production under batch system was a modified Gompertz equation. The kinetic parameters obtained in the experiment are summarized in Table 3. This model could predict the biogas production, the validity model can be checked based on the $\mathrm{R}^{2}$ value (Li et al., 2018). The values of $\mathrm{R}^{2}$ of the modified Gompertz was significantly high $(\mathrm{p}<0.05)$.

In order to evaluate the validity the model, the constants obtained conducted to the relevant equation and the biogas production; hence, the results obtained from the experiments compared with the model. As shown in the Figure 3, the value of biogas production obtained from the experiments and estimated by the models are close to each other, because of highly signficant $\mathrm{R}^{2}$ and were greater than $95 \%$.

The value of $A$ of $12000 \mathrm{mg} / \mathrm{L}$ is the value, amounting to $380.430 \mathrm{~mL} / \mathrm{mg}$ MLSS. It can be used as a control due to no SB action in the system. The gas produced from the degradation of endogenous process occurred in the system. Other compositions for various initial SB concentration indicated that the value of A depended on the MLSS, increasing the MLSS would increase the value of A. A significant reduction in the value of A occurred from 7200 to $4800 \mathrm{mg} / \mathrm{L}$ MLSS due to fewer microbes in the system (196.337 to $66.60,155.800$ to 66.00 and 128.200 to 54.00 ). If the SB system is compared with the previous model, cattle manure and water hyacinth (Patil et al., 2012), the A value of the experiments was lower than the previous results, the previous models indicated that gas formation took place with the degradation of organic substance than degradation of the endogenous in the batch system. Manure contains lignocellulosic material that requires a longer time for degradation to produce gas and the gas will continue to produce when the organic material in the manure was completely degraded. However, there was no toxic material in the manure that disturbed the microbe activity to degrade organic material, while water hyacinth

Table 3. Comparison kinetic constants between this study and other studies

\begin{tabular}{|c|c|c|c|c|c|c|c|}
\hline No & $\begin{array}{c}\text { Initial SB conc. } \\
(\mathrm{mg} / \mathrm{L})\end{array}$ & $\begin{array}{c}\text { MLSS } \\
\mathrm{mg} / \mathrm{L}\end{array}$ & $A(m L)$ & $M(m L)$ & $\wedge$ (day) & $\mathrm{R}^{2}$ & Authors \\
\hline \multirow[t]{4}{*}{1} & 50 & 2400 & 48.856 & 7.894 & 0.012 & 0.987 & \multirow{13}{*}{ This study } \\
\hline & & 4800 & 66.600 & 3.580 & 0.012 & 0.991 & \\
\hline & & 7200 & 196.337 & 13.206 & 0.012 & 0.991 & \\
\hline & & 9600 & 338.292 & 18.631 & 0.012 & 0.951 & \\
\hline \multirow[t]{4}{*}{2} & 100 & 2400 & 37.400 & 4.300 & 4.020 & 0.987 & \\
\hline & & 4800 & 66.000 & 4.429 & 1.600 & 0.991 & \\
\hline & & 7200 & 155.800 & 8.075 & 1.800 & 0.989 & \\
\hline & & 9600 & 330.400 & 16.007 & 1.300 & 0.951 & \\
\hline \multirow[t]{4}{*}{3} & 200 & 2400 & 38.500 & 2.257 & 2.1 & 1 & \\
\hline & & 4800 & 54.000 & 3.347 & 2.040 & 1.000 & \\
\hline & & 7200 & 128.200 & 5.275 & 1.52 & 0.971 & \\
\hline & & 9600 & 308.400 & 14.569 & 0.130 & 0.955 & \\
\hline 4 & 0 & 12000 & 380.430 & 18.940 & 0.010 & 0.951 & \\
\hline 5 & Cattle manure & & 418.260 & 9.490 & 4.460 & - & Budiyono et al.(2010) \\
\hline 6 & Water Hyacinth & & 449.4 & 27.9 & 6.625 & 0.981 & Patil et al. (2012) \\
\hline
\end{tabular}


was a waste from livestock that was the same as cattle manure (Syaichurrozi et al., 2013).

The results pertaining to the value of $\mu$ indicated that the greater the MLSS the greater the value of $\mu$. The value of $\mu$ indicated the rate of biogas formation. The highest value was achieved at the $12000 \mathrm{mg} / \mathrm{L}$ MLSS and amounted to $18.940 \mathrm{~mL}$, under the condition without any SB. Decreasing MLSS or increasing the SB resulted in a reduced value of $\mu$. Increasing the quantity of SB would suppress the gas formation because fewer microbes were available in the system. There was a significant reduction in the value of $\mu$ for the SB concentration of 100 and $200 \mathrm{mg} / \mathrm{L}$. The value of $\mu$ would dropped sharply for MLSS of 9600 to $7200 \mathrm{mg} / \mathrm{L}$. Lower concentration of SB would interfere with the gas formation to a lesser extent.

Mostly, the time required for growth rate of $\mu$ was 10 days. It can be predicted that the anaerobic process of SB degradation occurred 10 days before the stationary growth of gas formation for each series of experiment. The value of $\mu$ played an important role in the gas production, the high value of $\mu$ indicated that the gas formation was higher, the degradation of organic substance was also complete and resulted in high cumulative volume of gas. The result of the experiments was lower (for MLSS less than $7200 \mathrm{mg} / \mathrm{L}$ ) and higher (MLSS higher than $7200 \mathrm{mg} / \mathrm{L}$ ) than the value of $\mu$ obtained from cattle manure that contains lignocellulosic material taking longer time to degrade. The $\mu$ value of experiment was lower than for water hyacinth because contain more organic material and there was no material that interfere with the microbe activity.

\section{CONCLUSIONS}

The study focused on the batch anaerobic digestion of SB, especially on the MLSS concentration that resists the effect of SB as a preservative. At the end of the 60 days digestion time, the resultant MLSS was higher than $7200 \mathrm{mg} / \mathrm{L}$, being able to overcome the effect of SB for the initial concentration until $200 \mathrm{mg} / \mathrm{L}$. The value of kinetic constants of a modified Gompertz equation were highly significant based on the test of $\mathrm{R}^{2}$ with greater than $95 \%$ significant value. The optimum biogas production was observed at the first 10 days digestion time.

\section{Acknowledgements}

The authors wish to thank the Diponegoro University, Semarang, Central Java, Indonesia for providing financial support as per the project of this research.

\section{REFERENCES}

1. Annachhatre, A.P., Gheewala, S.H. 1996. Biodegradation of Chlorinated Phenolic Compounds, Biotechnology Advances, 14(1), 35-56.

2. Arias, J.L.O., Rocha, C.B., Santos, A.L.Q.S., Marube, L.C., Kupski, L., Caldas, S.S., Primel, E.G. 2019. Fast and simple method of simultaneous preservative determination in different processed foods by QuEChERS and HPLC-UV: Method development, survey and estimate of daily intake. Food Chemistry 293, 112-119.

3. Beezhold, B.L., C.S. Johnston, K.A. Nochta. 2014. Sodium benzoate-rich beverage consumption is associated with increased reporting of ADHD symptoms in college students: a pilot investigation, J. Atten. Disord. 18-236-241.

4. Birck, C., Degoutin, S., Maton, M., Neut, C., Bria, M., Moreau, M., Fricoteaux, F., Miri, V., Bacquet, M. 2016. Antimicrobial citric acid/poly(vinyl alcohol) crosslinked films: Effect of cyclodextrin and sodium benzoate on the antimicrobial activity, LWT - Food Science and Technology 68, 27-35.

5. Błędzka, D., Gromadzińska, J., \& Wąsowicz, W. 2014. Parabens. From environmental studies to human health. Environment International, 67, 27-42.

6. Budiyono, B., Widiasa, I.N., Johari, S., Sunarso. (2010). The kinetic of biogas production rate from cattle manure in batch mode. Int. J. Chem. Biol. Eng. 3(1), 39-44.

7. Budiyono, B., Syaichurrozi, I., Sumardiono, S. 2013. Biogas production from bioethanol waste: the effect of $\mathrm{pH}$ and urea addition to biogas production rate. Waste Technol. 1(1), 1-5.

8. Chen, H., Zhang, Y., Zhong, Q. 2019. Potential of acidified sodium benzoate as an alternative wash solution of cherry tomatoes: Changes of quality, background microbes, and inoculated pathogens during storage at 4 and $21^{\circ} \mathrm{C}$ post-washing. Food Microbiology 82, 111-118.

9. Dixit, S., Mishra, K.K., Khanna, S.K., Das. M. 2008. Benzoate and synthetic color risk assessment of fast food sauces served at street food joints of lucknow, India. Am. J. Food Technol 3, 183-191.

10. Egger, J., P.J. Graham, C.M. Carter, D. Gumley, J.F. Soothill. 1985. Controlled trial of oligoantigenic treatment in the hype, Lancet 325. 
11. Esimbekova, E.N., Asanova, A.A., Deeva, A.A., Kratasyuk, V.A. 2017. Inhibition effect of food preservatives on endoproteinases, Food Chemistry 235, 294-297.

12. Freedman, B.J. 1977. Asthma induced by sulphur dioxide, benzoate and tartrazine contained in orange drinks, Clin. Allergy 7, 407-415.

13. Fujihira, T., Seo, S., Yamaguchi, T., Hatamoto, M., Tanikawa, D. 2018. High-rate anaerobic treatment system for solid/lipid-rich wastewater using anaerobic baffled reactor with scum recovery, Bioresource Technology 263, 145-152.

14. Jacob, S.E., Hill, H., Lucero, H., \& Nedorost, S. 2016. Benzoate allergy in children-from foods to personal hygiene products. Pediatric Dermatology, 33(2), 213-215.

15. Jiang, Y., Wei, L., Zhang, H., Yang, K., Wang, H. 2016. Removal performance and microbial communities in a sequencing batch reactor treating hypersaline phenol-laden wastewater, Bioresour. Technol. 218, 146-152.

16. Kondusamy, D., Kalamdhad, S. 2014. Pre-treatment and anaerobic digestion of food waste for high rate methane production - A review. Journal of Environmental Chemical Engineering 2, 1821-1830.

17. Li, L., He, Q., Zhao, X., Wu, D., Wang, X., Peng, X. 2014. Anaerobic digestion of food waste: Correlation of kinetic parameters with operational conditions and process performance. Biochemical Engineering 130, 1-9.

18. Mpountoukas, P., A. Vantarakis, E. Sivridis, T. Lialiaris. 2008. Cytogenetic study in cultured human lymphocytes treated with three commonly used preservatives, Food Chem. Toxicol. 46, 2390-2393.

19. Nettis, E., M.C. Colanardi, A. Ferrannini, A. Tursi. 2004. Sodium benzoate-induced repeated episodes of acute urticaria/angio-oedema: randomized controlled trial, Br. J. Dermatol. 151, 898-902.

20. Noorafshan, A., M. Erfanizadeh, S. KarbalayDoust. 2014. Sodium benzoate, a food preservative, induces anxiety and motor impairment in rats, Neurosciences 19, 24-28.

21. Patil, J.H., Raj, M.A., Muralidhara, P.L., Desai, S.M., Raju, G.K.M. 2012. Kinetics of anaerobic digestion of water hyacinth using poultry litter as inoculum. Int. J.Environ. Sci. Dev. 3(2), 94-98.

22. Piper, J.D., \& Piper, P.W. 2017. Benzoate and sorbate salts: a systematic review of the potential hazards of these invaluable preservatives and the expanding spectrum of clinical uses for sodium benzoate. Comprehensive Reviews in Food Science and Food Safety, 16(5), 868-880.

23. Pongsavee, M. 2015. Effect of sodium benzoate preservative on micronucleus induction, chromosome break, and Ala40Thr superoxide dismutase gene mutation in lymphocytes, Bio Med Res. Int. 2015, 103512.

24. Reynolds, T.D., Richards, P.A. 1996. Unit Operations and processes in environmental engineering. Second Edition, PWS Publishing Company, An International Thomson Pblishing Company. Pp. 30.

25. Shahmohammadi, M. Javadi, M. Nassiri-Asl. 2016. An overview on the effects of sodium benzoate as a preservative in food products, Biotech Health Sci. August; 3(3):e35084.

26. Su, X., Wang, Y., Xue, B., Hashmi, M.Z., Lin, H., Chen, J., Wang, Z., Mei, R., Sun, F. 2019. Impact of resuscitation promoting factor $(\mathrm{Rpf})$ in membrane bioreactor treating high-saline phenolic wastewater: performance robustness and Rpf-responsive bacterial populations, Chem. Eng. J. 357, 715-723.

27. Sumantri, I., B. Budiyono, P. Purwanto. 2019. Kinetic Study of Anaerobic Digestion of Ketchup Industry Wastewater in a Three-stages Anaerobic Baffled Reactor (ABR). Bulletin of Chemical Reaction Engineering \& Catalysis, 14(2), 326-335.

28. Syaichurrozi, I., Budiyono, B., Sumardiono, S. 2013. Predicting kinetic model of biogas production and biodegradability organic materials: Biogas production from vinasse at variation of $\mathrm{COD} / \mathrm{N}$ ratio, Bioresource Technology 149, 390-397.

29. Tfouni, S.A., Toledo, MC. 2002. Estimates of themean per capita daily intake of benzoic and sorbic acids in Brazil, Food Addit. Contam. 19(7), 647-654.

30. Yadav, A., Kumar, A,. Das, M., Tripathi, A. 2016. Sodium benzoate, a food preservative, affects the functional and activation status of splenocytes at non cytotoxic dose, Food and Chemical Toxicology $88,40-47$.

31. Yusuf, M.O.L., Ify, N.L. 2011. The effect of waste paper on the kinetics of biogas yield from the codigestion of cow dung and water hyacinth. Biomass Bioenergy 35, 1345-1351.

32. Zhang, G and Ma, Y. 2013. Spectroscopic studies on the interaction of sodium benzoate, a food preservative, with calf thymus DNA. Food Chemistry $141,41-47$. 